\title{
The Influence of the Kampung Santri on The Economic Income of the Ciceri Jaya Community
}

\author{
Jamaluddin ${ }^{1}$, Nisa Nuranisa ${ }^{2}$, Anisa Fauziah ${ }^{3}$, Yulianis Utami ${ }^{4}$, Hedi Indra Lesmana ${ }^{5}$ \\ $\left.1^{*}\right), 2,3,4,5$ Universitas Islam Negeri Sultan Maulana Hasanuddin Banten \\ Email: jamaluddin@uinbanten.ac.id
}

\begin{abstract}
The international collaboration campaign is a program implemented between two countries, namely Indonesia and Malaysia. The two universities participating in this initiative are Sultan Maulana Hasanuddin Banten State Islamic University (UIN Banten) and Malaysia's Tun Hussein Onn University (UTHM). Several sub-themes will be implemented such as technology, economy, education, cultural history, and covid-19. Economics is one of the sub-themes to be discussed with two types of programs recommended by participants from the two countries in this sub-section, namely disseminating the application of daily financial records, and empowering the entrepreneurship of CiceripikKs. The selection of this program was planned based on the needs of the community / mahasantri in the Kampung Santri
\end{abstract}

Keywords: Higher Education, KUKERTA KI, Community service, Kampung Santri, and Ciceripik

\section{Introduction}

Community empowerment is an effort to provide power (empowerment) or strengthening (strengthening) to the community. Community empowerment is also defined as the ability of individuals who are united with the community in building the empowerment of the community concerned so that it aims to find new alternatives in community development (Mardikanto, 2014)

The purpose of this empowerment is also related to the objectives of our International Collaboration Real Work Lecture (KUKERTA KI) activity in Kampung Santri Ciceri Jaya. In addition to our striving and empowering the community, we also empower students who are thereby holding socialization on how to manage finances and socializing business empowerment with snacks, namely banana chips.

This activity does not escape the role of the community, by involving banana tree owners there as materials for making banana chips. And the role of society needed when marketing the product. This activity is expected to have an impact on progress in the economic sector for the people of Kampung Santri Ciceri Jaya.

\section{Literature or conceptual review}

Because one of the main goals of the Real Work Lecture program is so that students learn from experience to become problem solvers, village activities are planned and carried out by the students themselves by looking at the guidance and moral support from the KUKERTA Implementing Team, Field Supervisors, Village Officials, community leaders, Community Organizations, and Services / 
Agencies. Another main goal is that students are given the opportunity to experience the challenges of village development problems as a whole, and learn interdisciplinary and cross-sectoral ways of thinking. By paying attention to these objectives, on the other hand, student activities are not limited to their field of study. On the other hand, students are free to try to help solve all the problems faced by the village where they are placed, regardless of their field.

This students learn from experience which shows that development problems in all kinds of fields are actually related to one another and cannot be solved separately. A very fundamental role for further success after students leave the village is the role of a catalyst. A catalyst usually encourages the acceleration of the growth process, because other officials have separate tasks in the village.

Real Work Lecture is a form of education by providing learning experiences for students to live in the community outside the campus and directly identify and deal with development problems they are facing. This activity is carried out by universities to increase the content and weight of education for students and to get greater added value in higher education.

KUKERTA activities are carried out outside the campus to increase the relevance of higher education to the development and needs of the community for science, technology, and art to carry out increasing development, as well as increase student perceptions of the relevance of the curriculum studied on campus with the reality of development in society.

For students, KUKERTA activities must be carried out as a new understanding of learning and that will never be obtained on campus. KKN must emphasize aspects of the learning experience that link academic concepts with the realities of people's lives.

This KUKERTA program reflects theoretical knowledge that is synergized with experience in the field and is expected to be able to improve student personality and foster self-confidence in social life. With the completion of KUKERTA students must increase their potential and feel they have new knowledge, new abilities, and new awareness about society, nation, and homeland as well as about himself, which will be very useful as provisions to become a scholar.

The KUKERTA program implemented by higher education institutions has been started since 1950 with an activity called Student Mobilization. This activity aims to reduce the gaps in progress (which is generally the effect of education) between Java and Outside Java. At that time, students were deployed to areas, especially outside Java, to dedicate themselves and ${ }^{1}$ practice their knowledge, especially in the field of rural community development such as establishing schools, carrying out movements to eradicate illiteracy, and physical development (although with/within various limitations) .

The Student Mobilization Program is considered very successful. This is evidenced by the reality that in a relatively short period of time, regions outside Java have succeeded in establishing secondary schools, which in turn have had a major influence on the awakening of the spirit of development in all corners of the country. The success of this program is not without the need for a sacrifice for the perpetrators, namely students. Among the sacrifices made were the students' study time being longer, and many of them could not finish their studies or were "forced to stay " in the villages because the local people really expected their presence. According to David Berry (2003), defining roles as the expectations imposed on individuals who have a certain social position. These expectations are a balance of social norms and therefore it can be said that the role is determined by the norms in society. In that role, there are two expectations, namely the expectations that the role holder has towards society or the person who carries out his role or obligations. So it can be seen that aroup of regular behavior, which is caused by a certain position, or because of the existence of an office that is easily recognized. The personality of a person may also greatly influence how influencing interests should be exercised. The path arises because a person understands that he is not working alone. It has the environment, which is needed to be reliable at all times. The environment is wide and varied, and each will have a different environment. But the role that must be played is essentially no different.

\footnotetext{
${ }^{1}$ Akhyadi, Ade Sadikin. "Kuliah Kerja Nyata Mahasiswa Universitas Pendidikan Indonesia Perkembangan Kognisi Sosial, Kredibilitas Dan Daya Tarik" hal.1
} 
From the above statement that the goals and objectives of KKN are a group of people who influence and can be relied on by the community who build development efforts carried out by the KKN group and are accepted by the community with various regular series of behaviors. ${ }^{2}$

\section{International Collaboration Cooperative Model with UTHM}

Kukerta International Collaboration is a community service program that is collaborative between two universities of different countries. This collaboration paper has a special role that is different from the usual Kerta. This international Kukerta is usually held abroad or following the agreement between the two countries. However, the condition of Covid-19 is currently sweeping the world, UIN Banten is holding an International Collaboration Tournament with Universiti Tun Hussein Onn Malaysia virtually or online. The two universities carry out collaborative work programs online, there are no meetings and no inter-country departures. Therefore In this case the implementation is limited to working in their respective countries and the results of the Kerta process are translated through a virtual zoom.

\section{Method}

\section{Formation of Student Groups and Field Supervisory Lecturers}

Group formation is prioritized to answer problems that occur in society, for example in the fields of economy, education, technology, and socio-culture. Also, problems that have only occurred some time ago were also included in the field of training, namely Covid-19. The formation of groups is based on the concept of notes that students make during the selection process. The number of team members is 3-4 students from Sultan Maulana Hasanuddin Banten State Islamic University and 9-10 students from Universiti Tun Hussein Onn Malaysia. Meanwhile, field supervisors consisting of one lecturer from the Indonesian campus and 1 person from the Malaysian campus are adjusted to their educational background and experience.

\section{International Collaboration Cukerta Preparation}

The university collaborates with one of the universities in Malaysia, namely Tun Hussein Onn Malaysia University to jointly serve the people of Kampung Santri. Before being deployed to the location, students are provided with online training, both about a brief description of the location and about the methods to be used for research.

The method used is the PAR method carried out by the LPPM and Field Supervisory Lecturers (DPL). In this method, students are taught how to form, foster, fill and develop existing potentials by following steps such as observation and identification of potential and community needs, making work programs, and implementing work programs.

Debriefing is also provided to DPL, so that they can understand the concept and operation. DPL is required to be able to answer the problems faced by students in empowering the community in the Santri Village.

\section{Observation and Identification of Community Potentials}

activity begins with the mapping of the Santri Village which includes the number of dormitories, mosques, and the number of business actors in the Kampung Santri. Then identified problems and potentials in the community through observation and interviews. The potential can be developed, especially in the economic sector, through the work program that will be carried out. At this stage, it is

\footnotetext{
${ }^{2}$ M iftah Thoha . 2012. Prilaku Organisasi Konsep Dasar dan Implikasinya. Jakarta: PT Bumi Aksara
} 
very necessary to identify the potential of community institutions to serve as a means for the development of the Kampung Santri.

\section{Preparation of Work Programs}

According to Arikunto and Jabar (2009: 3), there are two definitions for the term "program": Program can be defined in a special sense and program in a general sense. The general understanding of the program is a form of plan that will be carried out. "Program" if it is directly related to program evaluation, the program is defined as a unit or activity unit which is the realization or implementation of policies, takes place in a continuous process, and occurs in an organization involving a group of people.

In this case, what is meant by a work program is an arrangement of work activity plans that have been jointly designed and agreed to be implemented within a certain period. The work program must be made in a piecemeal fashion because it will become the organization's guide in achieving a goal. And besides that, the work program itself can also be a benchmark in achieving targets when doing work, and the results will be evaluated at the end of the management.

The work program is compiled from the results of observations and identification of problems and potential in the field. Based on the identification of problems in the community, it can be concluded that students are not yet financially independent because they are still dependent on scholarships and parents. Also, students and the community have not been able to manage their finances properly, so they complain about their finances. There are no community organizations engaged in the economic sector in the Santri Village environment.

The program arranged is the socialization of how to properly manage personal finances and empowerment of business for Mahasantri. The socialization program on how to manage personal finances was carried out once during my participation. Meanwhile, business empowerment for mahasantri was carried out temporarily because it still needed confirmation to the mahasantri and the management of the Santri Village through further discussion. ${ }^{3}$

\section{Development and Consultation with various parties}

To carry out a work program, support, and cooperation with other parties are needed. Therefore, the work program that has been made is discussed again with Teh Tatu as the Village Head of the Kampung Santri, Kang Ifan as the manager of the Santri Village, Pak Jamaludin, ME as Puan Wan Aina Mardhaih Wan Zahari as the Field Supervisor, and friends from the economic group from the campus. UTHM. As a result, they agreed to support the work program that had been created by providing directions to always maintain the good name of the campus and implement health protocols to avoid Covid-19.

\section{Result and Discussion}

\section{Socialization about how to manage personal finances}

Godwin and Koonce (1992) in Parrota and Johnson (1998) state that personal financial management can be a process of financial planning, implementation and evaluation carried out by individuals or families. ${ }^{4}$ Financial planning is defined as the process of achieving life goals, namely a prosperous and happy future through financial management. Personal financial management is very important because it becomes a person's financial foundation regarding the use of funds that are owned to be allocated appropriately. Also, it requires discipline and self-control towards excessive

\footnotetext{
${ }^{3}$ Jabrohim, dan Aman, M oehamad, dan Sudaryani, Rina Ratih Sri "Pedoman Pelaksanaan Kuliah Kerja Nyata M uhammadiyah Untuk Negeri" 2015. Hal.2

${ }^{4}$ Peter Garlans Sina, "M otivasi sebagai Penentu Perencanaan Keuangan (Studi Pustaka)", Jurnal Ilmiah Akuntansi dan Bisnis, Vol. 9 No. 1, Januari 2014. Hal.47
} 
consumption of products or services. For the allocation of funds to be sufficient, we must adhere to the principle of prioritizing needs not wants. Because human desires are very numerous so that whatever money they have will never be enough to fulfill these desires. ${ }^{5}$

Here are 11 ways to live a smart and frugal life that you can do:

a. Priority: needs and wants This method is powerful enough to reduce expenses, namely by scheduling groceries with a list to buy. Do not enter the purchase of goods only because of desire.

b. Expenses <Income Try not to get into debt to make ends meet. Therefore, make a list of priority needs.

c. Maintain health Take care of your health, because when someone has a disease, the funds needed for treatment or handling are not small. This can affect the amount of expenditure more than income.

d. Be wise in shopping to Be wise in choosing items to buy, especially when someone is in a supermarket where a comfortable and clean place tends to shop in large quantities, especially when they offer sales of goods at discounted prices.

e. Cheap vacation facilities Take vacations according to financial means because a fantastic vacation will increase one's expenses. This will then have an impact on stress due to inappropriate allocation of funds.

f. Bring lunch Bring supplies from home to save on expenses because besides being cheap, they are also safe, clean, and healthy for consumption.

g. Buy investment goods Transfer liquid funds to in-kind, such as land. This will increase one's income in the future because land prices are always increasing and do not require maintenance.

h. Go green The trick is to save unused electricity, for example by turning off the light switch when not in use and so on.

i. Don't underestimate a dime Collect change from a change in the purchase of goods, because it is possible that change can help when someone is pressed.

j. Implement a simple lifestyle As much as a person's income, he will never feel enough because human desires are unlimited. Start controlling expenses with a simple life.

k. Discipline in saving Be disciplined in saving for funds in the future. ${ }^{6}$

This program aims at students to be able to properly manage personal finances made easy with the application "Financial Diary " which can be used online or offline and can be downloaded for free through the play store. Because almost all students have a smartphone so that it is easy to use it more effectively.

In addition to providing information, students are given time to share their experiences in managing personal finances. This can be used as joint learning and increase their confidence to speak in front of a crowd because most students consist of first semester students. This program also gives appreciation to these students by providing English books and cold drinks for personal consumption.

\section{Business empowerment for mahasantri}

Community empowerment is a concept of economic development that forms a new paradigm from the summary of community values which are people-centered, participatory, empowering, and

\footnotetext{
${ }^{5}$ Soya Sobaya, et al, "The Influence of Financial Literacy and Social Environment on Employee Financial Planning at the Islamic University of Indonesia Yogyakarta", Madania Journal Vol. 20 No. 1, 2016, Pg. 115.

${ }^{6}$ Kharisma Danang Yuangga, et al, "Cultivating Thorough Living Habits by Using Piggy Banks in Cidokom Village, Gunung Sindur District". Journal of Pengabdian Dharma Laksana Serving the Country Vol. 2 No. 2, 2020, pg. 149-151.
} 
sustainable (Chamber, 1995) 7 . Business empowerment, namely empowering a group to be able to establish a business together by providing encouragement, motivation, and providing awareness of existing potentials and opportunities. Based on the potential that exists in Santri Village, we see that banana trees can grow anywhere so that it can benefit people who want to sell them without having to go to the market. Besides, the strategic location of the Santri Village between the campus, offices, and densely populated settlements makes it easy to market access. This program has a student target with the aim that they can be financially independent.

The business carried out is banana chips with the name CiceripikKs. The name CiceripikKs comes from the words Ciceri, Pik, and Ks. Ciceri is the name of the place where the Kampung Santri is located, namely Ciceri Jaya. Pik comes from the word Kripik, a kind of thin snack and is generally fried until crispy. Meanwhile, Ks stands for "Kampung Santri" where we carry out the training. Also, the Kampung Santri is also a production site for the next CiceripikKs together with mahasantri who have committed to developing this product together.

Marketing can be done through mahasantri social media and the marketplace (Shopee), especially at the time of the Covid-19 pandemic so it is more effective to reduce physical contact with other people. Marketing is done by adding a photo of CiceripikKs that has been given a logo designed from the collaboration between students of Universiti Tun Hussein Onn Malaysia with original flavors, Chocolate, and Matcha. Also, the results of customer reviews are added to increase the confidence of comments on the product. At the beginning of the promotion, the price for CiceripikKs was Rp. 5000 while the normal price for the original variant is priced at Rp. 8000 and Chocolate and Matcha flavors Rp. 100,000. Furthermore, the public, especially business actors and students who are not the CiceripikKs team, can become resellers.

\section{Guidance and Monitoring}

KUKERTA participating students consist of people who have no experience in approaching and collaborating with both government and private institutions and the community. Therefore, this activity needs to be supported by guidance and monitoring from Field Supervisors. The guidance starts from approaching the community, seeking government and private support, identifying potentials and problems in the community, and solving problems that become the Real Work Lecture program, namely socialization on how to manage good personal finances and empowering businesses for students.

\section{Making Reports, Journals, and Books}

KKN reports need to be made as accountability to the Higher Education as well as the Public. Student reports are made online systematic consisting of an introduction, process preparation of a work program steps activities in developing and developing Posdaya, the problems encountered, support obtained, conclusions and suggestions, including attachments for photos of KKN activities. Likewise, the Institute for Service to Community (LPPM) of Higher Education as a Team The organizers of the International KKN make a report which describes all the steps that have been done and the results obtained. ${ }^{8}$

Reports, journals, and books resulting from the implementation of Real Work Lectures are a form of accountability to the campus and society. This activity report is made in a video with a duration of fewer than 10 minutes which consists of all KUKERTA KI activities, from observation to implementation of work programs. The journal is made systematically which consists of an introduction, the process of compiling the work program, problems encountered, support obtained,

\footnotetext{
${ }^{7}$ M unawar Noor, "Pemberdayaan M asyarakat”, Jurnal Ilmiah CIVIS, Volume I, No 2, Juli 2011. Hal. 88.

${ }^{8}$ Anwas, Oos M. “Kuliah Kerja Nyata Tematik Pos Pemberdayaan Keluarga Sebagai M odel Pengabdian M asyarakat Di Perguruan Tinggi" hal. 8
} 
conclusions, and suggestions, including attached photos for group documentation. For a more detailed explanation of the activities during the Real Work Lecture, it is described in the form of a book entitled "Strengthening the Economy of the Santri Village in the Collaborative Training Program ".

\section{Evaluation and Follow Up}

Arikunto and West Java (2009: 18) say that the purpose of holding program evaluations is to determine the achievement of program objectives by knowing the implementation of program activities. Seven elements must be done according to Brikerhoff (1986: ix) in Arikunto and West Java, for the implementation of evaluation, namely: 1) determining the focus to be evaluated (focusing the evaluation), 2) preparing the evaluation design (designing the evaluation), 3) information collection (collecting information), 4) analysis and interpretation of information (analyzing and interpreting), 5) making reports (reporting information), 6) managing evaluation (managing evaluation), and 7) evaluation for evaluation (evaluating evaluation).

The objectives of program evaluation as described by Roswati (2008: 66-67) are as follows: 1) answering questions about the follow-up of a program in the future, 2) delaying decision making, 3) shifting responsibilities, 4) justifying / program justification, 5) fulfilling accreditation needs, 6) accounting reports for funding, 7) responding to requests by assigners, required information, 8) helping staff development programs, 9) studying impacts/consequences not by the plan, 10) conducting improvement efforts for ongoing programs, 11) assessing the benefits of ongoing programs, 12) providing input for new programs.

As a final process, the Real Work Lecture will be assessed which results will affect the student achievement index. The assessment team is carried out by Field Supervisors and the International Collaboration Real-Life Lecture Implementation Team. Assessment is carried out based on student debriefing and mentoring, preparation of work programs, student performance (attendance, activities, and behavior), and output in the form of reports, journals, and books. Real Work Lecture is carried out continuously, therefore for the business empowerment work program involving a group of students who will together be responsible for continuing the banana chips business (CiceripikKs). Apart from that, see market interest in our products will apply for halal certification to the ministry of health to increase consumer confidence in the product. Tertiary Education Institutions can monitor and evaluate after Real Work Lecture and if community empowerment is still weak it can be followed up by Real Work Lectures in the next period or can be used as research conducted by Higher Education. ${ }^{9}$

\section{Conclusions and suggestions}

International Collaboration Real Work Lecture is a form of community service by applying the knowledge that students get to solve problems in society and develop existing potentials with cooperation between the Sultan Maulana Hasanuddin Banten State Islamic University and Universiti Tun Hussein Onn Malaysia. Seeing the time of the Real Work Lecture which is not up to two weeks, the program created is the socialization of managing personal finances with the application and empowering the snack business (CiceripikKs).

Managing personal finances with applications that can be used online and offline makes it easier for students to record expenses and income efficiently. Also, the empowerment of the banana chips (CiceripikKs) business is considered to be able to compete in the market because of innovations with

\footnotetext{
${ }^{9}$ M unthe, Ashiong P. "Pentingnya Evaluasi Program Di Institusi Pendidikan : Sebuah Pengantar, Pengertian, Tujuan dan Manfaat". Hal. 7
} 
original, chocolate, and matcha flavors. Both programs can be used by students for free. Meanwhile, the business empowerment program is considered to be able to improve the mahasantri economy.

International Collaboration Real Work Lecture is a form of student service to the community which is carried out in the Santri Village. Empowerment of businesses with the main target of mahasantri requires follow-up and support from various parties, especially local governments, and local communities in its development. In addition, Sultan Maulana Hasanuddin State Islamic University can participate in solving problems that exist in the community of Kampung Santri because the campus is close so that it can take part in joint social responsibility

\section{Daftar Pustaka}

Akhyadi, Ade Sadikin. Kuliah Kerja Nyata Mahasiswa Universitas Pendidikan Indonesia Perkembangan Kognisi Sosial, Kredibilitas dan Daya Tarik. Diakses pada tanggal 11 Desember 2020

Anwas, Oos M. Kuliah Kerja Nyata Tematik Pos Pemberdayaan Keluarga Sebagai Model Pengabdian Masyarakat Di Perguruan Tinggi: hlm 8. Diakses pada tanggal 14 Desember 2020

https://scholar.google.com/scholar?hl=id\&as $\mathrm{sdt}=0 \% 2 \mathrm{C} 5 \& \mathrm{q}=$ pengertian+program + kerja\&oq=pengertian + program $+\# \mathrm{~d}=\mathrm{gs}$ qabs\& $\mathrm{u}=\% 23 \mathrm{p} \% 3 \mathrm{DFKRV9qGCehMI}$

Jabrohim, Aman, Moehamad, Sudaryani, Rina Ratih. 2015. Pedoman Pelaksanaan Kuliah Kerja Nyata Muhammadiyah Untuk Negeri. Diakses pada tanggal 11 Desember 2020

Kharisma Danang Yuangga, et al, "Cultivating Thorough Living Habits by Using Piggy Banks in Cidokom Village, Gunung Sindur District". Journal of Pengabdian Dharma Laksana Serving the Country Vol. 2 No. 2, 2020, pg. 149-151.

Miftah Thoha . 2012. Prilaku Organisasi Konsep Dasar dan Implikasinya. http://ejournal.upbatam.ac.id/index.php/jim/article/view 915.

Munawar Noor, "Pemberdayaan Masyarakat", Jurnal Ilmiah CIVIS, Volume I, No 2, Juli 2011. Hal. 88.

Munthe, Ashiong P. Pentingnya Evaluasi Program Di Institusi Pendidikan : Sebuah Pengantar, Pengertian, Tujuan, dan Manfaat. : hlm 7. Diakses pada tanggal 14 Desember 2020

Noor, Munawar. 2011. Pemberdayaan Masyarakat. Jurnal Ilmiah CIVIS. 1(2). Hal. 88.

Sanulika, A., Maradina, J., \& Muanifah, S. (2020). Meningkatkan bonafiditas laporan keuangan UMKM scale up Tangerang Selatan melalui Sistem Informasi Aplikasi Pencatatan Informasi Keuangan (SI-

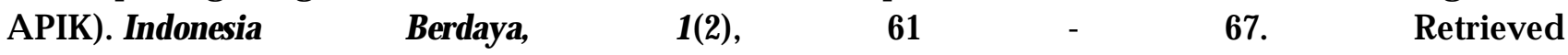
from https:/hkinstitute.org gournals/ib/article/view/N1i209

Sina, Peter Garlans. 2014. Motivasi sebagai Penentu Perencanaan Keuangan (Studi Pustaka). Jurnal Ilmiah Akuntansi dan Bisnis, 9(1), Hal.47.

Sobaya, Soya, Hidayanto M. Fajar \& Junaidi Safitri. 2016. Pengaruh Literasi Keuangan dan Lingkungan Sosial Terhadap Perencanaan Keuangan Pegawai di Universitas Islam Indonesia Yogyakarta. Jurnal Madania, Vol 20 (1), Hal. 115.

Susanti, I., \& Lestari, F. (2020). Teknologi pengolahan karbol dari limbah cair Serai wangi (cymbopogon $\begin{array}{llllll}\text { nordus). Indonesia } & \text { Berdaya, } & 1(1), & 1 & - & 6 .\end{array}$ from https://ukinstitute.org gournals/ib/article /view/v1i101 
Yuangga, Kharisma Danang, Jasmani, Irmal, Dede Supiyan \& Dian Rostikawati. 2020. Menumbuhkan Kebiasaan Hidup Cermat dengan Memanfaatkan Celengan di Lingkungan Desa Cidokom Kecamatan Gunung Sindur. Jurnal Pengabdian Dharma Laksana Mengabdi Untuk Negeri, 2(2), Hal. 149-151. 
